\title{
Suppression of Annual Bluegrass in Creeping Bentgrass Putting Greens Using Plant Growth Regulators
}

\author{
Paweł Petelewicz ${ }^{1}$, Paweł M. Orliński ${ }^{1}$, and James H. Baird ${ }^{1}$
}

AdDitional INDEX wORDs. Agrostis stolonifera, flurprimidol, paclobutrazol, Poa annua, trinexapac-ethyl

Summary. Decreased stand uniformity together with reduced aesthetics and playability caused by annual bluegrass (Poa annua) intrusion in creeping bentgrass (Agrostis stolonifera) putting greens is one of the major problems that golf course superintendents face with managing newer playing surfaces. Few herbicides are registered for selective control of annual bluegrass in creeping bentgrass greens, and the risk of herbicide resistance remains an issue, thus use of plant growth regulators (PGRs) is still the primary method of annual bluegrass suppression. This study was conducted to evaluate eight PGR treatments, employed as a series of 15 consecutive, biweekly applications to suppress annual bluegrass encroachment in 'Pure Distinction' creeping bentgrass maintained as a golf course putting green in Los Angeles, CA. Best annual bluegrass suppression was observed with products containing flurprimidol (FP) at $0.256 \mathrm{lb} /$ acre, paclobutrazol (PB) at $0.119 \mathrm{lb} / \mathrm{acre}$, or three-way mixture of FP, trinexapac-ethyl (TE), and PB (FP + PB + TE) at $\mathbf{0 . 0 5 5}$, 0.014 , and $0.055 \mathrm{lb} /$ acre, respectively. Although all treatments caused some significant creeping bentgrass injury, which increased over time, PB at $0.119 \mathrm{lb} / \mathrm{acre}$ and $\mathrm{FP}+\mathrm{PB}+\mathrm{TE}$ at $\mathbf{0 . 0 5 5}, 0.014$, and $0.055 \mathrm{lb} /$ acre, respectively, appeared to be safest among effective treatments. Additionally, those treatments caused significantly darker green turf, which may be desirable on putting greens. This research confirms the potential of PGR use to limit annual bluegrass infestation on creeping bentgrass greens in a Mediterranean climate and reveals the most effective treatments that could be used in a putting green maintenance program.

$\mathrm{C}$ reeping bentgrass (Agrostis stolonifera) is the most adapted and desirable turfgrass species for golf course putting greens in most temperate climates. However, one of the major challenges that golf course superintendents face with managing newer creeping bentgrass playing surfaces is invasion from annual bluegrass [Poa annua (Askew, 2017; Flessner et al., 2017; Green et al., 2019)]. Annual bluegrass is one of the most pervasive, adaptable,

Received for publication 17 Sept. 2020. Accepted for publication 10 Dec. 2020.

Published online 22 January 2021

${ }^{1}$ Department of Botany and Plant Sciences, University of California Riverside, 900 University Avenue, Riverside, CA 92521

This work was supported by the California Turfgrass \& Landscape Foundation (CTLF) and U.S. Department of Agriculture, National Institute of Food and Agriculture, Hatch project 1002711 . We thank Brian Sullivan and Justin DePippo, former and current superintendent, respectively, at Bel-Air Country Club, Los Angeles, CA, for hosting this study.

J.H.B. is the corresponding author. E-mail: jbaird@ ucr.edu.

This is an open access article distributed under the CC BY-NC-ND license (https://creativecommons.org/ licenses/by-nc-nd/4.0/).

https://doi.org/10.21273/HORTTECH04737-20 and diverse plant species in the world (Cross et al., 2015). Although it can also provide a high-quality putting surface, annual bluegrass is more susceptible to biotic and abiotic stress than creeping bentgrass and thus it often requires significantly higher maintenance inputs, including pesticides, fertilizer, and irrigation, for survival. Moreover, annual bluegrass often flowers profusely, which can disrupt putting surface uniformity and ball roll (Han et al., 2017; Yelverton, 2015).

Annual bluegrass control in putting greens is currently managed through a combination of proper cultural practices and chemical applications (Flessner et al., 2013; Xiong et al.,
2015). Cultural management practices reported to reduce annual bluegrass intrusion in creeping bentgrass putting greens include planting creeping bentgrass cultivars with increased density, clipping removal during annual bluegrass seedhead production, interseeding creeping bentgrass, shade reduction, nitrogen $(\mathrm{N})$ and phosphorus $(\mathrm{P})$ fertilization reduction, top-dressing, drainage improvement, soil moisture reduction, aeration, and thatch control (Baldwin, 1993; Baldwin and Brede, 2011; Gaussoin and Branham, 1989; Patton et al., 2019; Raley et al., 2013; Rossi, 2001). Despite best management practices, annual bluegrass often reinvades or persists due to an exhaustive seed bank in the soil (Adams, 1989; Baldwin, 1993; Rossi, 2001). Moreover, mitigating annual bluegrass infestation with cultural practices can be marginally effective; therefore, there is still a need for selective chemical control of this species (Baldwin, 1993; Brosnan et al., 2013; Raley et al., 2013).

There is a narrow range of herbicidal active ingredients registered for selective annual bluegrass in creeping bentgrass putting greens in the United States; therefore, options for its effective eradication are limited (Flessner et al., 2013; Haguewood et al., 2013). Bensulide has been the only preemergence herbicide labeled for putting greens; however, it provides insufficient annual bluegrass control at recommended rates and significant bentgrass injury with higher use rates (Askew and McNulty, 2014). Methiozolin (PoaCure; Moghu Research Center, Yuseong, South Korea) offers great promise for selective preemergence and postemergence control of annual bluegrass in creeping bentgrass greens. Although methiozolin was granted registration by the U.S. Environmental Protection Agency (USEPA) in late 2019 , registration was still pending in a few states, including California, at the time of writing (Golfdom, 2019).

\begin{tabular}{llll}
\hline $\begin{array}{l}\text { Units } \\
\text { To convert U.S. to SI, } \\
\text { multiply by }\end{array}$ & U.S. unit & SI unit & $\begin{array}{l}\text { To convert SI to U.S., } \\
\text { multiply by }\end{array}$ \\
\hline 0.3048 & $\mathrm{ft}$ & $\mathrm{m}$ & 3.2808 \\
407.4583 & gal $/ 1000 \mathrm{ft}^{2}$ & $\mathrm{~L} \cdot \mathrm{ha}^{-1}$ & 0.0025 \\
2.54 & inch $(\mathrm{es})$ & $\mathrm{cm}$ & 0.3937 \\
25.4 & inch $(\mathrm{es})$ & $\mathrm{mm}$ & 0.0394 \\
48.8243 & lb/1000 $\mathrm{ft}^{2}$ & $\mathrm{~kg} \cdot \mathrm{ha}^{-1}$ & 0.0205 \\
1.1209 & lb/acre & $\mathrm{kg} \cdot \mathrm{ha}^{-1}$ & 0.8922 \\
$\left({ }^{\circ} \mathrm{F}-32\right) \div 1.8$ & ${ }^{\circ} \mathrm{F}$ & ${ }^{\circ} \mathrm{C}$ & $\left({ }^{\circ} \mathrm{C} \times 1.8\right)+32$
\end{tabular}


Another way of minimizing annual bluegrass infestation in creeping bentgrass greens is the use of Class- $\mathrm{B}$ plant growth regulators (PGRs) to differentially suppress annual bluegrass growth in mixed stands with creeping bentgrass (Miller, 2016; Turgeon, 2012). The idea behind this management practice is to shift the competitive advantage away from annual bluegrass and to the desirable turfgrass (Flessner et al., 2013). Class-B PGRs are rootabsorbed chemicals that suppress plant growth through the inhibition of gibberellin biosynthesis, resulting in the reduction of cell elongation and associated expansive growth of susceptible plants. In comparison, Class-A PGRs, including trinexapac-ethyl [TE (Primo Maxx; Syngenta Crop Protection, Greensboro, NC)] act similarly but are shoot-absorbed. Although PGRs can substantially affect vertical growth in both species, the creeping bentgrass stolons continue to spread into areas occupied by regulated annual bluegrass and begin to displace it (Bigelow et al., 2007; Turgeon, 2012). The most commonly used Class-B PGRs are paclobutrazol [PB (Trimmit 2SC; Syngenta Crop Protection)] and flurprimidol [FP (Cutless MEC; SePRO Corp., Carmel, IN)]. The efficacy of these active ingredients in regard to annual bluegrass suppression has been previously reported (Johnson and Murphy, 1995, 1996; McCullough et al., 2013; Woosley et al., 2003). However, it has been reported that their efficacy is highly dependent on the environment/location, application rates, and timing (Patton et al., 2019; Reicher et al., 2015). Moreover, the need for the use of long-term sequential application programs was emphasized because reinvasion might occur when treatments cease. Also, especially in cases of high infestation levels, these compounds are not able to completely eliminate annual bluegrass (McCullough et al., 2013; Rossi, 2001). Apart from the differential annual bluegrass suppression, the use of Class-B PGRs can result in a variety of positive changes, including color improvement (darkening), increased shoot density, and decreased mowing needs (Jeffries et al., 2013; Koski, 1997; Kreuser et al., 2018; Turgeon, 2012; Woosley et al., 2003). On the contrary, Class-A PGRs, including TE, provide excellent growth suppression compared with $\mathrm{PB}$ or FP but do not result in effective annual bluegrass suppression. Nevertheless, TE can induce seedhead suppression; therefore, it is considered a positive addition to PGR mixes for annual bluegrass suppression (Bigelow et al., 2007).

Annual bluegrass adaptability to different growing conditions and robust genetic diversity coupled with limited herbicidal products available to turf managers pose a real threat to developing herbicide-resistant populations (Breeden et al., 2017; Cross et al., 2015; McCullough et al., 2013). To date, the resistance to various types of herbicides in annual bluegrass are observed more often than in any other turfgrass weed (Breeden et al., 2017; Heap, 2020). Therefore, the use of PGRs supported by cultural practices aimed at giving the competitive advantage to creeping bentgrass remains the primary means of annual bluegrass suppression in putting greens (Hoisington et al., 2014). Identification of the most effective and least injurious PGR products is crucial. Therefore, this study was conducted to evaluate various rates and formulations of commonly available PGRs to control annual bluegrass infestation in creeping bentgrass maintained as a golf course putting green in a coastal southern California climate.

\section{Materials and methods}

STUDY SITE AND ENVIRONMENTAL CONDITIONs. The study was conducted from May 2017 through the end of Apr. 2019 on a practice putting green at Bel-Air Country Club (Los Angeles, CA; USDA plant hardiness zone $10 \mathrm{~b}$; elevation, $\approx 452 \mathrm{ft}$ ). Environmental data for the site (California Irrigation Management Information System station 99 in Santa Monica) are provided in Table 1 . The study area was a 3-year-old, mature 'Pure Distinction' creeping bentgrass green established from seed on 6 inches of root zone mix that comprised $85 \%$ sand and $15 \%$ peat with physical properties conforming to United States Golf Association (USGA) recommendations.

Mowing RegIme. The green was mowed 4 to $5 \mathrm{~d}$ per week with a reel mower ranging from 0.095 to 0.110 inches, depending on season and environmental conditions. The mowing frequency decreased during winter months (December through February) as well as when heavy rainfall occurred. The green did not receive any type of rolling.

IrRigation REgIME. Throughout the study, the green was irrigated with 0.25 to 0.5 inches of water per night, 6 to $7 \mathrm{~d}$ per week in the summer months. Irrigation was less frequent during the winter months due to cooler weather conditions and precipitation. Hand watering was provided as needed to prevent wilt. Soil volumetric water content (VWC) using time domain reflectometry (FieldScout TDR 350; Spectrum Technologies, Aurora, IL) readings ranged from $20 \%$ to $40 \%$ and were used by the golf course maintenance staff to determine how much water was needed to replenish the turf. Irrigation was also provided when needed following pesticide applications.

Fertilization. In 2017, the green received low rates of primary and secondary nutrients due to an impending reconstruction of the other putting greens. Total $\mathrm{N}$ applied during that year was less than 1.50 $\mathrm{lb} / 1000 \mathrm{ft}^{2}$ using foliar applications and one granular application $(18 \mathrm{~N}-$ $1.3 \mathrm{P}-14.9 \mathrm{~K}$ at $0.50 \mathrm{lb} / 1000 \mathrm{ft}^{2} \mathrm{~N}$ on 24 Oct. 2017).

In 2018, the total amount of $\mathrm{N}$ applied to the green increased, totaling less than $3.00 \mathrm{lb} / 1000 \mathrm{ft}^{2} \mathrm{~N}$. That year, starting from April, the green began receiving foliar applications of fertilizers that included 0.07 to $0.10 \mathrm{lb} / 1000 \mathrm{ft}^{2} \mathrm{~N}$ every 7 to $10 \mathrm{~d}$. Three granular applications were also performed in $2018(14 \mathrm{~N}-3.1 \mathrm{P}-$ $11.6 \mathrm{~K}$ at $0.50 \mathrm{lb} / 1000 \mathrm{ft}^{2} \mathrm{~N}$ on 3 Mar. 2018, followed by $11 \mathrm{~N}-24 \mathrm{P}-$ $0 \mathrm{~K}$ at $1.00 \mathrm{lb} / 1000 \mathrm{ft}^{2} \mathrm{P}$ and $0 \mathrm{~N}-0 \mathrm{P}-$ $41.5 \mathrm{~K}$ at $1.00 \mathrm{lb} / 1000 \mathrm{ft}^{2} \mathrm{~K}$, both on 11 June 2018).

In 2019, leading up to $25 \mathrm{Apr}$, the green received a total of $0.90 \mathrm{lb} /$ $1000 \mathrm{ft}^{2} \mathrm{~N}$ as a foliar spray only. The application regime followed a similar rotation as in previous years, with applications every 7 to $14 \mathrm{~d}$.

O T H E R M A I N T E N A N C E PRACTICES. Standard cultural practices were used for golf course putting green maintenance, including fungicide applications when needed. However, no other PGRs were applied to the green during the study evaluation period.

Treatments. Throughout the study, treatments were applied as a set of 15 consecutive spraying events 
Table 1. Monthly total reference evapotranspiration (ETo), total precipitation, and average air and soil temperatures for the Los Angeles Basin, CA (California Irrigation Management Information System Station 99, Santa Monica, CA) during the study of annual bluegrass suppression with plant growth regulators in a 'Pure Distinction' creeping bentgrass putting green in 2017-19, at Bel-Air Country Club, Los Angeles, CA.

\begin{tabular}{|c|c|c|c|c|c|c|c|c|c|c|c|c|}
\hline \multirow[b]{2}{*}{ Season } & \multicolumn{12}{|c|}{ Month } \\
\hline & $\overline{\text { May }}$ & June & July & Aug. & Sept. & Oct. & Nov. & Dec. & Jan. & Feb. & Mar. & Apr. \\
\hline \multicolumn{13}{|c|}{ Total ETo $(\text { inches })^{\mathrm{z}}$} \\
\hline $2018-19$ & 4.8 & 5.6 & 6.4 & 6.2 & 4.4 & 3.9 & 3.0 & 2.3 & 2.1 & 2.2 & 4.2 & 4.7 \\
\hline \multicolumn{13}{|c|}{ Total precipitation (inches) } \\
\hline $2017-18$ & 0.1 & 0.1 & 0.0 & 0.0 & 0.1 & 0.0 & 0.3 & 0.0 & 1.5 & 0.1 & 4.4 & 0.0 \\
\hline $2017-18$ & 61.0 & 64.5 & 68.7 & 69.3 & 69.3 & 67.7 & 63.6 & 61.0 & 61.2 & 56.8 & 57.1 & 59.5 \\
\hline $2018-19$ & 60.5 & 64.0 & 70.5 & 71.3 & 66.9 & 65.6 & 63.1 & 57.5 & 57.0 & 52.1 & 58.4 & 60.1 \\
\hline \multicolumn{13}{|c|}{ Average soil temperature $\left({ }^{\circ} \mathrm{F}\right)$} \\
\hline $2017-18$ & 64.1 & 68.2 & 72.1 & 72.2 & 69.9 & 65.4 & 61.3 & 55.2 & 57.3 & 57.1 & 58.8 & 63.4 \\
\hline $2018-19$ & 65.3 & 68.2 & 72.8 & 73.3 & 70.1 & 65.9 & 61.6 & 58.3 & 57.3 & 56.7 & 61.7 & 65.6 \\
\hline
\end{tabular}

${ }^{\mathrm{z}} 1$ inch $=2.54 \mathrm{~cm} .\left({ }^{\circ} \mathrm{F}-32\right) \div 1.8={ }^{\circ} \mathrm{C}$.

executed on a 2 -week interval. The first set of treatments was initiated on 1 May 2017. Reapplication (second set of treatments) was initiated on 30 Apr. 2018. A total of eight PGR treatments and an untreated control were tested during this study as described in Table 2. All treatments were applied using a carbon dioxide $\left(\mathrm{CO}_{2}\right)$ powered backpack sprayer (Bellspray, Opelousas, LA) equipped with four flat-fan spray tips (8004VS VisiFlo; TeeJet Technologies, Wheaton, IL) and strainers with check valves (4193A-5-50; TeeJet Technologies) installed on the boom with 9 -inch spacing and calibrated to deliver $2 \mathrm{gal} / 1000 \mathrm{ft}^{2}$ of spray solution. The green was irrigated with 0.1 to 0.2 inches of water immediately after each application.

Assessments. Evaluation was performed on a biweekly schedule for 2 years, starting on 1 May 2017 and ending on 29 Apr. 2019, for a total of $\mathbf{5 2}$ data collection events (26 per season). Over the course of the trial, plots were visually evaluated for the following: percentage of annual bluegrass cover $(0 \%$ to $100 \%)$; turfgrass injury with treatments on 0 to 10 scale (where 0 represented no visible phytotoxicity symptoms, 3 was maximum acceptable injury, and 10 represented complete loss of turf), visual green color evaluated on turf on a 1 to 9 scale (where 9 represented the darkest shade of green color, 6 represented minimum acceptable green color level, and 1 was no green color within the plot area) and normalized difference vegetation index (NDVI) using a handheld crop sensor (GreenSeeker; Trimble Agriculture, Westminster, $\mathrm{CO}$ ).

ExPERIMENTAL DESIgN AND Statistical analysis. Study design was a complete randomized block (CRB) with four replications. Plot size was $4 \times 6 \mathrm{ft}$, with 2 -ft alleys. Data collected throughout the study were averaged for each month and analyzed using an analysis of variance (Statistica 10; StatSoft, Tulsa, OK) for each parameter separately; the means were compared using Fisher's protected least significant difference test at the $0.05 P$ level $(P \leq 0.05)$. When appropriate, Pearson's correlation coefficient was calculated using the same software.

\section{Results and discussion}

AnNual bluegrass cover. Statistical analysis revealed significant differences in the average annual bluegrass cover between seasons ( $\mathrm{Ta}$ ble 3), with the species more than tripling in cover during the second year of the study (Table 4). Annual bluegrass cover was $\approx 10 \%$ at the beginning of the study in May 2017, and its distribution was suitably uniform across the study area. Initially, the population decreased naturally during the summer months of 2017 , as evidenced by the untreated control. Throughout that time, only the three-way PGR mixture (FP+PB+TE) and $\mathrm{PB}$ alone at $2 \times$ rate $(\mathrm{PB} 2 \times)$ showed significant decreases in annual bluegrass cover when compared with the control (Fig. 1). No other differences were observed until Aug. 2017, when annual bluegrass cover increased to initial levels and all of the treatments, with the exception of FP $0.5 \times$, resulted in significantly decreased annual bluegrass cover. Within the following 3 months, annual bluegrass cover decreased again and started to reappear slowly in November, with steadily increasing cover in the untreated control until the end of the first season of the study (Fig. 1). Previous research also noted seasonal fluctuations of annual bluegrass populations in untreated plots that were associated with the lifecycle of a winter annual species (Bigelow et al., 2007; McCullough et al., 2005). No significant differences among the PGR treatments and untreated control were reported from Nov. 2017 until Jan. 2018, except for PB $2 \times$, which showed significantly lower annual bluegrass cover compared with the untreated control in Sept. 2017 and Dec. 2017 (Fig. 1). Early reports by Kageyama et al. (1989) and Neylan et al. (1997) demonstrated the ability of $\mathrm{PB}$ to transition turf from a mixed stand of annual bluegrass and creeping bentgrass to predominantly creeping bentgrass. It was also reported that PB applied multiple times throughout the growing season to a creeping bentgrass and annual bluegrass mixed fairway 
Table 2. List of plant growth regulator treatments and application timing (dates) during the study of annual bluegrass suppression with plant growth regulators in a 'Pure Distinction' creeping bentgrass putting green in 2017-19 at Bel-Air Country Club, Los Angeles, CA.

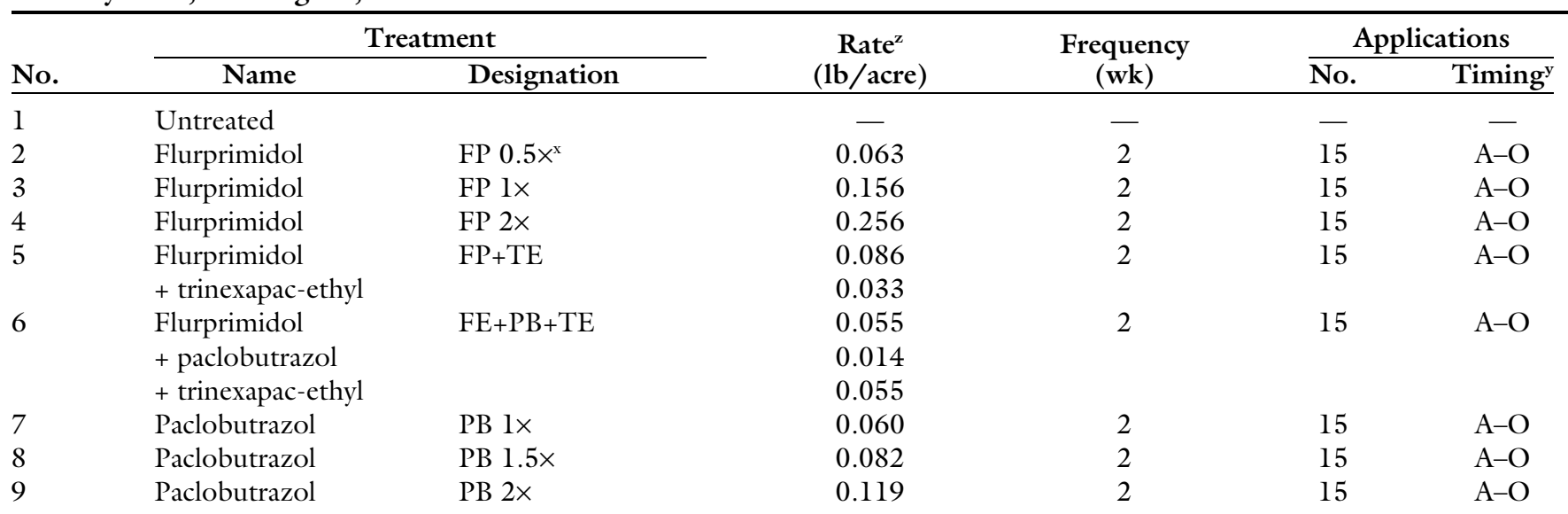

${ }^{\mathrm{y}}$ Application dates

\begin{tabular}{lllrlllll} 
A & 1 May 2017 & 30 Apr. 2018 & F & 10 July 2017 & 9 July 2018 & K & 18 Sept. 2017 & 17 Sept. 2018 \\
B & 15 May 2017 & 14 May 2018 & G & 24 July 2017 & 23 July 2018 & L & 2 Oct. 2017 & 1 Oct. 2018 \\
C & 30 May 2017 & 29 May 2018 & H & 7 Aug. 2017 & 6 Aug. 2018 & M & 16 Oct. 2017 & 15 Oct. 2018 \\
D & 12 June 2017 & 11 June 2018 & I & 21 Aug. 2017 & 20 Aug. 2018 & N & 30 Oct. 2017 & 29 Oct. 2018 \\
E & 26 June 2017 & 25 June 2018 & J & 5 Sept. 2017 & 4 Sept. 2018 & O & 13 Nov. 2017 & 12 Nov. 2018 \\
\hline
\end{tabular}

${ }^{\mathrm{z}} \mathrm{l} \mathrm{lb} / \mathrm{acre}=1.1209 \mathrm{~kg} \cdot \mathrm{ha}^{-1}$

yApplication timing (dates).

${ }^{x}$ FP (Cutless MEC; SePRO Corp., Carmel, IN); FP+TE (Legacy; SePRO Corp.); FE+PB+TE (Musketeer; SePRO Corp.); and PB (Trimmit 2SC; Syngenta Crop Protection, Greensboro, NC).

Table 3. Results of an analysis of variance test of the effects of season, treatment, and term and their interactions on annual bluegrass cover and creeping bentgrass injury following the application of plant growth regulators in 2017-19 at BelAir Country Club, Los Angeles, CA.

\begin{tabular}{lcc}
\hline Item & Annual bluegrass cover & Creeping bentgrass injury \\
\hline Season & $*$ & $* * *$ \\
Treatment & $*$ & $*$ \\
Term & $*$ & $*$ \\
Season $\times$ treatment & $*$ & NS \\
Season $\times$ term & $*$ & $*$ \\
Treatment $\times$ term & $*$ & $*$ \\
Season $\times$ treatment $\times$ term & $* * *$ & $*$ \\
\hline
\end{tabular}

${ }^{*},{ }^{* *},{ }^{* *}$ Significant at $P \leq 0.05,0.01$, or 0.001 , respectively. NS $=$ not significant at $P \leq 0.05$.

stand can reduce annual bluegrass populations by $\approx 85 \%$ (Woosley et al., 2003). A recent study conducted in Indiana by Patton et al. (2019) showed successful annual bluegrass reduction with $\mathrm{PB}$ used both alone and in combination with bensulide. On the contrary, Jeffries et al. (2013) obtained poor annual bluegrass suppression on a creeping bentgrass green with stand-alone $\mathrm{PB}$ regimens at 8 weeks after the initial application. The authors explained that this poor performance might have been caused by the limited application window. Nevertheless, during the same study, PB increased amicarbazone herbicide efficacy when added to a regimen.

As annual bluegrass pressure increased within our study area during 2018, more differences were revealed. From Feb. 2018 to the end of the second year of the study, most of the PGR treatments resulted in decreased annual bluegrass cover when compared with the control (data not shown), although differences among PGRs were found only in March and April, when the lowest amount of annual bluegrass cover was discovered with $\mathrm{FP}+\mathrm{PB}+\mathrm{TE}, \mathrm{PB} 2 \times, \mathrm{FP} 1 \times$, and $\mathrm{FP}$ $2 \times$ (Fig. 1). Early greenhouse studies showed that the FP capacity inhibited annual bluegrass emergence and early growth (Gaussoin and Branham, 1987; Haley and Fermanian, 1989). The potential of FP to reduce annual bluegrass populations in the field was reported by Shoop et al. (1986), who evaluated its performance during the spring on mixed fairway stands with creeping bentgrass. The authors also demonstrated that higher rates were more successful for suppression.

The second year of our study started with doubled populations of annual bluegrass in the untreated control that steadily increased until the end of the summer. Some fluctuation in weed visibility was observed between Sept. 2018 and Jan. 2019, which was followed by a rapid increase of annual bluegrass plants. Ultimately, the annual bluegrass cover of the untreated control peaked at $55 \%$ by the end of the experiment (Fig. 1). When compared with the untreated control, no significant differences were shown with FP $0.5 \times$ throughout the second year of the study, and almost no significant differences with the two-way PGR mixture were evident by Feb. 2019. 
Table 4. Impact of flurprimidol (FP), paclobutrazol (PB), and trinexapac-ethyl (TE) plant growth regulators applied at various rates as standalone products or two-way $(\mathrm{FP}+\mathrm{TE})$ and/or three-way $(\mathrm{FP}+\mathrm{PB}+\mathrm{TE})$ mixtures (as described in Table 2 ) on average annual bluegrass cover and average creeping bentgrass injury (10 = highest) in $2017-19$ at Bel-Air Country Club, Los Angeles, CA.

\begin{tabular}{|c|c|c|c|c|c|c|}
\hline \multirow[b]{2}{*}{ Treatment } & \multicolumn{3}{|c|}{ Annual bluegrass cover ( $0 \%$ to $100 \%)$} & \multicolumn{3}{|c|}{ Creeping bentgrass injury ( $0-10$ scale) } \\
\hline & $\begin{array}{l}\text { Season I } \\
2017-18\end{array}$ & $\begin{array}{l}\text { Season II } \\
2018-19\end{array}$ & $\begin{array}{c}\text { Treatment } \\
\text { mean }\end{array}$ & $\begin{array}{l}\text { Season I } \\
2017-18\end{array}$ & $\begin{array}{l}\text { Season II } \\
2018-19\end{array}$ & $\begin{array}{c}\text { Treatment } \\
\text { mean }\end{array}$ \\
\hline FP $0.5 \times$ & $5.8 \mathrm{gh}$ & $22.1 \mathrm{~b}$ & $13.9 \mathrm{~b}$ & $0.5 \mathrm{e}$ & $0.5 \mathrm{e}$ & $0.5 \mathrm{e}$ \\
\hline FP $1 \times$ & $4.7 \mathrm{~h}$ & $13.4 \mathrm{~d}$ & $9 \mathrm{~d}$ & $1.0 \mathrm{c}$ & $1.1 \mathrm{bc}$ & $1.1 \mathrm{bc}$ \\
\hline FP $2 \times$ & $4.3 \mathrm{~h}$ & $9.8 \mathrm{ef}$ & $7.1 \mathrm{de}$ & $1.6 \mathrm{a}$ & $1.7 \mathrm{a}$ & $1.6 \mathrm{a}$ \\
\hline $\mathrm{PB} 1 \times$ & $5 \mathrm{gh}$ & $12.1 \mathrm{de}$ & $8.6 \mathrm{~d}$ & $0.6 \mathrm{de}$ & 0.8 cde & $0.7 \mathrm{de}$ \\
\hline PB $1.5 \times$ & $5.6 \mathrm{gh}$ & $12.3 \mathrm{de}$ & $9 \mathrm{~d}$ & 0.8 cde & $1.0 \mathrm{~cd}$ & $0.9 \mathrm{~cd}$ \\
\hline PB $2 \times$ & $3.5 \mathrm{~h}$ & $7.7 \mathrm{fg}$ & $5.6 \mathrm{e}$ & $1.11 \mathrm{c}$ & $1.5 \mathrm{ab}$ & $1.3 \mathrm{~b}$ \\
\hline Season mean & $5.1 \mathrm{~b}^{\mathrm{y}}$ & $14.5 \mathrm{a}$ & & $0.8 \mathrm{a}$ & $0.9 \mathrm{a}$ & \\
\hline
\end{tabular}

${ }^{\mathrm{z}}$ Means within a column followed by the same letter are not statistically different at $P \leq 0.05$ according to Fisher's protected least significant difference test.

${ }^{\mathrm{y}}$ Means (season) within a row followed by the same letter are not statistically different at $P \leq 0.05$ according to Fisher's protected least significant difference test.

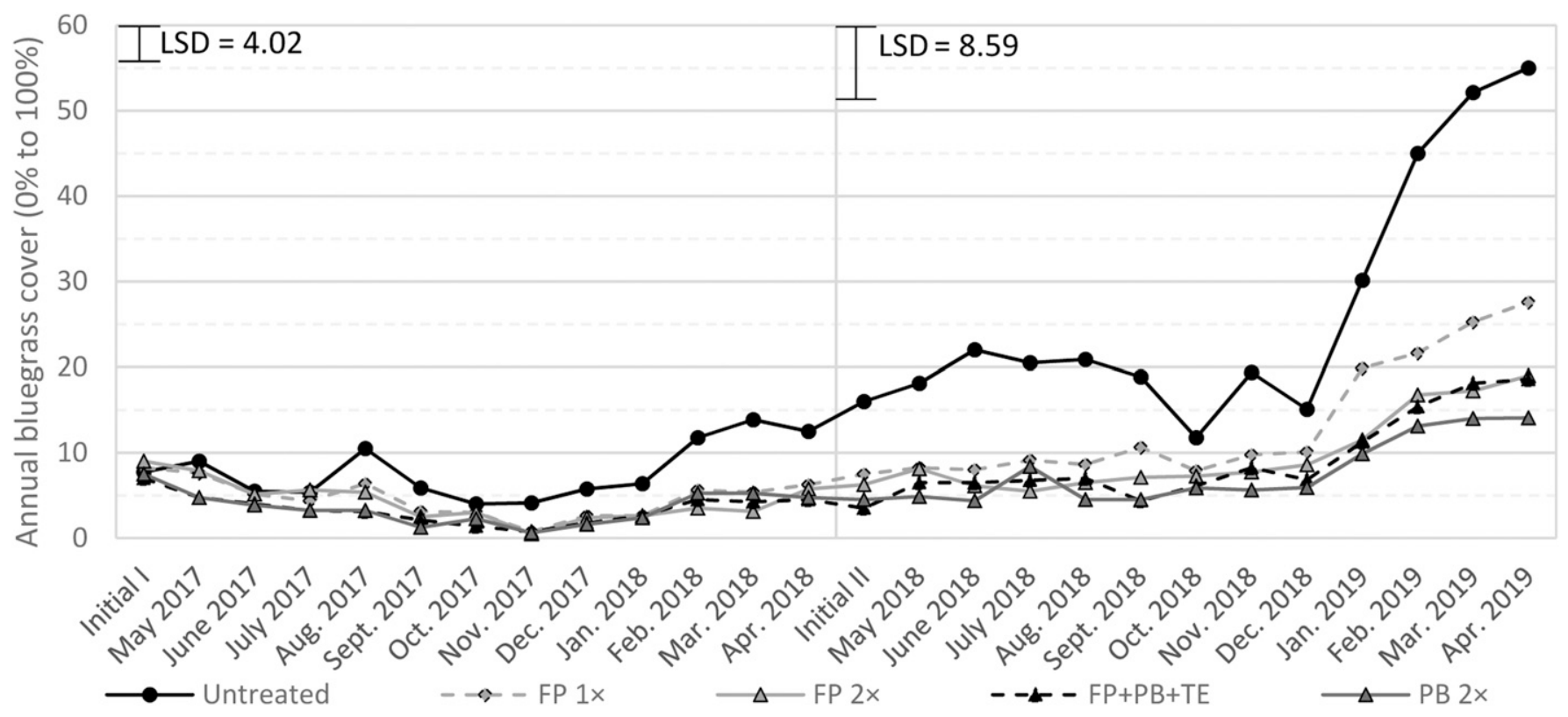

Fig. 1. Effects of selected plant growth regulators flurprimidol (FP), trinexapac-ethyl (TE), and paclobutrazol (PB) and their two-way $(\mathrm{FP}+\mathrm{TE})$ and/or three-way $(\mathrm{FP}+\mathrm{PB}+\mathrm{TE})$ mixtures applied at various rates (described in Table 2) on annual bluegrass cover in comparison with the untreated control in 2017-19 at Bel-Air Country Club, Los Angeles, CA. Least significant difference values (LSD) are based on Fisher's protected test at $P \leq 0.05$. The data of each year are analyzed separately.

Except for Oct. 2018 and Dec. 2018, when no differences among treatments were shown, generally all of the remaining PGR treatments resulted in decreased annual bluegrass cover (data not shown). Although significant differences among those treatments for each month observed by Feb. 2019 occurred rather sporadically, the lowest annual bluegrass cover resulted from
$\mathrm{PB} 2 \times, \mathrm{FE}+\mathrm{PB}+\mathrm{TE}$, and $\mathrm{FP} 2 \times$, and those treatments resulted in significantly lower average annual bluegrass cover for the second year of the study (Fig. 1, Table 4).

Differences in efficacy among the PGR treatments were dependent on annual bluegrass pressure. With low infestation levels, most of the treatments seemed to suppress annual bluegrass at an acceptable level.
However, when annual bluegrass encroachment increased, only a few treatments, mainly at higher rates, appeared to be successful. It was previously shown that maximum or even higher than recommended PGR rates were the most effective for annual bluegrass suppression (Woosley et al., 2003). Ervin et al. (2017) tested $\mathrm{PB}$ rates higher than those on the label in programs to eradicate 
annual bluegrass from creeping bentgrass; they managed to reduce the infestation level from $\approx 45 \%$ to $8 \%$ with $\mathrm{PB}$ alone, but full eradication was impossible. This is also consistent with our results and those of other reports (Johnson and Murphy, 1996; Reicher et al., 2015; Woosley et al., 2003). In contrast to Bigelow et al. (2007), who reported successful annual bluegrass suppression in creeping bentgrass fairways with stand-alone FP at 0.28 or 0.56 $\mathrm{kg} \cdot \mathrm{ha}^{-1}(0.250$ or $0.500 \mathrm{lb} / \mathrm{acre})$ and when the latter rate was mixed with $\mathrm{TE}$ at $0.06 \mathrm{~kg} \cdot \mathrm{ha}^{-1}(0.054 \mathrm{lb} /$ acre), the mixture of TE and FP in our study did not enhance annual bluegrass suppression. In the case of a three-way PGR mixture, the additive effect seemed to originate from the combination of FP and PB rather than TE. Another study showed effective annual bluegrass reduction with the use of PB (and mixtures with TE) on creeping bentgrass fairways, and also reported no annual bluegrass suppression enhancement from the addition of $\mathrm{TE}$ in the mixture (McCullough et al., 2005).

In general, the best performing treatments for annual bluegrass suppression in this study appeared to be $\mathrm{FP} 2 \times, \mathrm{PB} 2 \times$, and $\mathrm{FP}+\mathrm{PB}+\mathrm{TE}$. However, when PGR treatments were ended, annual bluegrass populations started to recover and develop. Among sequential PGR programs (up to 12 applications per season) tested in three separate locations (Indiana, Michigan, Nebraska) over the course of 4 years, it was indicated that $\mathrm{PB}$ and $\mathrm{FP}$ were the most effective PGRs to reduce annual bluegrass infestation in creeping bentgrass greens, whereas the twoway mixture of FP and TE was less effective (Reicher et al., 2015); although the authors did not test three-way PGR mixtures, their results were consistent with ours.

Creeping bentgrass injury WITH PLANT GROWTH REGULATORS. Some slight damage was observed in untreated plots in both years; however, the average injury level did not exceed 0.1 , and no statistically significant differences were found between seasons regarding average creeping bentgrass injury (Table 4). The highest average injury to creeping bentgrass resulted from FP $2 \times$, followed by $\mathrm{PB} 2 \times$ and $\mathrm{FP} 1 \times$. The lowest average injury was found with $\mathrm{FP}$ $0.5 \times$; statistically, it was no different from the remaining PGR treatments (Table 4).

Injury caused by PGRs was first seen in May 2017. It was demonstrated by creeping bentgrass thinning and increased with time in all treatments, peaking in Dec. 2017. FP $2 \times$ caused the highest turf injury at that time. Soon after, turf started to recover rapidly. However, some damage to creeping bentgrass (also in the untreated control) occurred soon before the resumption of PGR applications in the second year of the study, which was mainly demonstrated by turf browning and desiccation. It is highly likely that this occurrence resulted from exposure to lower temperatures and/or prolonged insufficient fertility and irrigation in Mar. and Apr. 2018. Furthermore, with reapplication of PGRs, thinning reappeared and mounted in a manner similar to that during the previous season. However, in 2018, injury peaked between July and August, and the highest level of injury among PGRs was caused by PB $2 \times$ and FP $2 \times$. In contrast to the previous season, recovery from PGR-induced injury was longer and phytotoxicity effects in some cases persisted until the end of the evaluation. However, no significant differences were reported among PGRs and the untreated control starting from Jan. 2019 (Fig. 2).

In general, although annual bluegrass cover differed among years, the injury pattern remained similar; therefore, turf injury was a direct consequence of the PGR treatments. Creeping bentgrass injury in this study might also be attributed to the decreased growth rate in the summer months and high temperatures, as well as repeatedly applied PGRs over time that accumulated throughout the course of the study.

The correlation between air temperature and creeping bentgrass injury was insignificant for the untreated control; however, at the same time, it was significant for all PGR treatments. Of all treatments, this correlation was weakest for the three-way mixture of FP, TE, and $\mathrm{PB}$ when compared with high rates of FP and $\mathrm{PB}$ alone, indicating that the mixture was safer when used during high temperatures and comparably successful for annual bluegrass suppression. The turf injury was also more associated with the general increase in temperature than with short-term temperature extremes; the correlation of creeping bentgrass injury and average minimum air temperature was stronger than that between creeping bentgrass injury and average maximum air temperature (Table 5 ). The maximum injury with FP $2 \times$ and PB $2 \times$ was also significantly higher in both years and in the second year only, respectively, when compared with $\mathrm{FP}+\mathrm{PB}+\mathrm{TE}$ (Fig. 2). At the end of each season, the total $\mathrm{FP}$ and $\mathrm{PB}$ rates applied to turf with $\mathrm{FP}+\mathrm{PB}+\mathrm{TE}$ were $0.825 \mathrm{lb} /$ acre and $0.21 \mathrm{lb} /$ acre, respectively; however, for the $2 \times$ rates, they were $1.995 \mathrm{lb} /$ acre and $3.84 \mathrm{lb} /$ acre, respectively. The correlation between annual bluegrass cover and creeping bentgrass injury was significant for all PGR treatments and insignificant for the untreated control. Although all of the correlations were considered weak, the lowest values of the correlation coefficient were obtained for FP $\mathrm{I} \times$ and PB $2 \times(\mathrm{r}=-0.24$ for both $)$, followed by FP $0.5 \times$ and $\mathrm{FP}+\mathrm{PB}+\mathrm{TE}(\mathrm{r}=$ -0.26 for both) (Table 5 ). This indicated that as annual bluegrass cover increased, creeping bentgrass injury decreased. Therefore, higher PGR rates were more effective for annual bluegrass suppression, although such success was associated with higher turfgrass injury. When considering the efficacy of those treatments, $\mathrm{PB}$ $2 \times$ and $\mathrm{FP}+\mathrm{PB}+\mathrm{TE}$ appeared to be the safest among the best performing PGR treatments.

Most of our findings are contrary to those previously reported in regard to PGR effects on turfgrass quality. Neylan et al. (1997) observed no adverse impact on turf with PB, whereas all treatments evaluated during their study showed acceptable turf quality. No adverse effects and improved creeping bentgrass quality were also reported by Bell et al. (2004). In addition, Jeffries et al. (2013) observed some significant and unacceptable injury to turfgrass with amicarbazone treatments; this was alleviated when $\mathrm{PB}$ was added to the regime. Furthermore, PB standalone treatments in their study had comparable or improved quality when compared with the untreated control. Ervin et al. (2017) reported that PB treatments typically resulted 


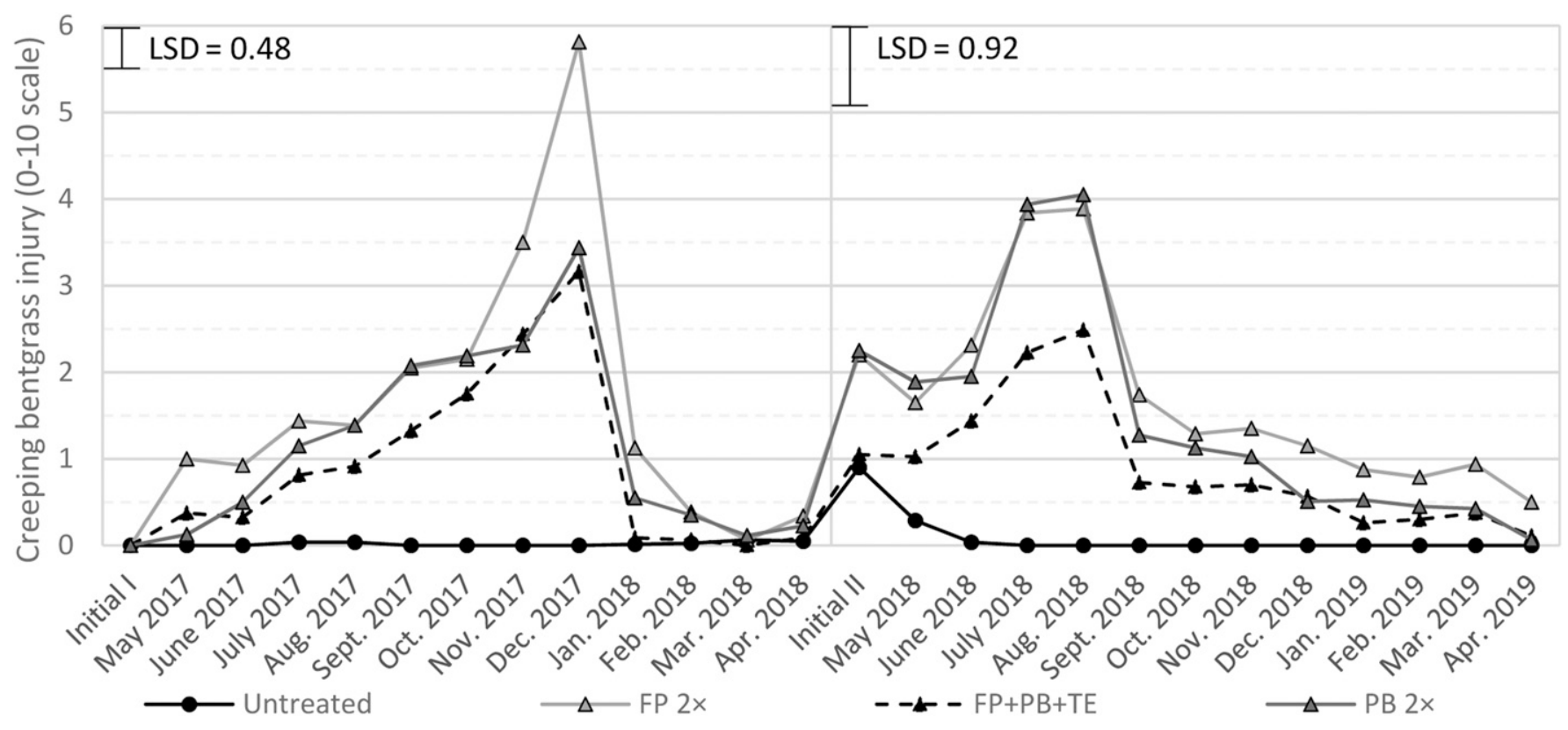

Fig. 2. Effects of selected plant growth regulators flurprimidol (FP), trinexapac-ethyl (TE), and paclobutrazol (PB) and their two-way $(\mathrm{FP}+\mathrm{TE})$ and/or three-way $(\mathrm{FP}+\mathrm{PB}+\mathrm{TE})$ mixtures applied at various rates (described in Table 2$)$ on creeping bentgrass injury $(0=$ no visible phytotoxicity symptoms; $3=$ maximum acceptable injury; $10=$ complete loss of turf $)$ compared with the untreated control in 2017-19 at Bel-Air Country Club, Los Angeles, CA. Least significant difference values (LSD) are based on Fisher's protected test at $P \leq \mathbf{0 . 0 5}$. The data of each year are analyzed separately.

Table 5. Correlation coefficients of creeping bentgrass injury, normalized difference vegetation index (NDVI), and annual bluegrass cover as well as environmental data separated by plant growth regulators [i.e., flurprimidol (FP), paclobutrazol (PB), and trinexapac-ethyl (TE)] applied at various rates as standalone products or two-way (FP + TE) and/or three-way $(\mathrm{FP}+\mathrm{PB}+\mathrm{TE})$ mixtures (described in Table 2) in 2017-19 at Bel-Air Country Club, Los Angeles, CA.

\begin{tabular}{|c|c|c|c|c|c|}
\hline Treatment & Avg air temp & Avg minimum air temp & Avg maximum air temp & Annual bluegrass cover & NDVI \\
\hline Untreated & -0.08 & -0.05 & -0.13 & -0.07 & -0.51 \\
\hline FP $0.5 \times$ & 0.40 & 0.43 & 0.34 & -0.26 & -0.35 \\
\hline FP $1 \times$ & 0.70 & 0.72 & 0.65 & -0.24 & 0.13 \\
\hline FP $2 \times$ & 0.72 & 0.74 & 0.67 & -0.29 & 0.00 \\
\hline $\mathrm{FP}+\mathrm{TE}$ & 0.68 & 0.71 & 0.63 & -0.28 & 0.12 \\
\hline $\mathrm{FP}+\mathrm{PB}+\mathrm{TE}$ & 0.61 & 0.62 & 0.57 & -0.26 & -0.06 \\
\hline PB 2x & 0.67 & 0.69 & 0.61 & -0.24 & -0.04 \\
\hline
\end{tabular}

in superior turf quality when compared with the untreated control. However, the authors perceived the incidence of reduced quality with PB during a few rating events in late spring and late fall, and they concluded that this might have been an indicator of phytotoxicity. Koski (1997) reported some minor shortterm (7-14 d) phytotoxicity with PB treatments; however, in time, the overall quality of treated turf improved (Koski 1997). Although turf injury in our trial was significant, a similar pattern was observed, indicating that turf recovery followed when PGR treatments were ceased. This was especially apparent during the first year of the study before fertility was increased. This also suggests that inadequate nutrition might have had only a partial impact on the increased injury to turf. Reicher et al. (2015) also reported no severe damage was caused by PGRs to creeping bentgrass. In Indiana, TE and a mixture of FP and TE occasionally improved the quality of the turfgrass stand; however, in another location (Michigan), the same authors reported the occurrence of thinning caused by the treatments, similar to our findings. It is possible that only Baldwin and Brede (2011) observed significant injury to creeping bentgrass with $\mathrm{FP}$ and $\mathrm{PB}$ in both study locations (Idaho and Washington). Overall, turf injury never exceeded the limit for acceptable damage, and no turf loss occurred. The authors also suggested that the main factor contributing to the observed damage was the occurrence of low temperatures, which was only a minor issue in our study. Ervin et al. (2017) observed both effective control of annual bluegrass and voids in the turf canopy due to the use of an aggressive PB program. Although it was not an issue in our trial, such a risk should also be considered when using PGRs.

VISUAL GREEN COLOR AND NDVI. The visually estimated green color intensity in the untreated 
control persisted throughout the period of evaluation on a level exceeding the minimally acceptable threshold (score of 6). All of the PGR treatments used during the study caused creeping bentgrass darkening (Fig. 3 ), which may be desirable on putting greens (Bigelow et al., 2007; Koski, 1997). Although no differences were shown among PGR treatments, all resulted in significantly darker

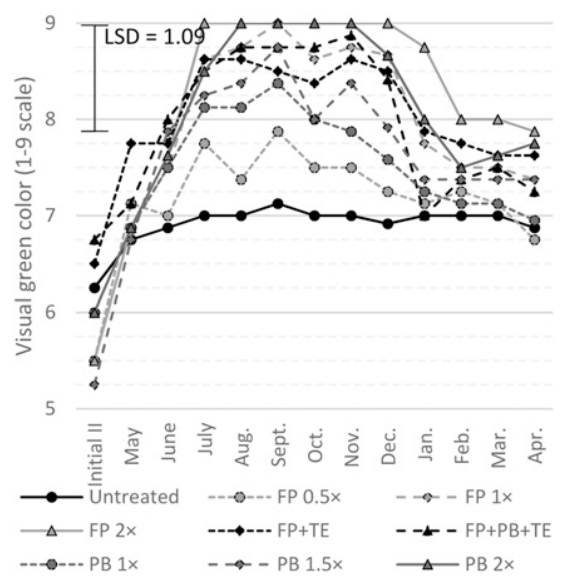

Fig. 3. Effects of selected plant growth regulators flurprimidol (FP), trinexapac-ethyl (TE), and paclobutrazol (PB) and their two-way $(\mathrm{FP}+\mathrm{TE})$ and/or three-way $(\mathrm{FP}+\mathrm{PB}+\mathrm{TE})$ mixtures applied at various rates (described in Table 2 ) on creeping bentgrass visually evaluated green color $(9=$ darkest shade of green color; $6=$ minimum acceptable green color; 1 = no green color within the plot area) in comparison with the untreated control in 2018-19 at BelAir Country Club, Los Angeles, CA. Least significant difference values (LSD) are based on Fisher's protected test at $P \leq 0.05$.

Table 6. Correlation coefficients of visual color and annual bluegrass cover, creeping bentgrass injury, and normalized difference vegetation index (NDVI) separated by plant growth regulators [i.e., flurprimidol (FP), paclobutrazol (PB), and trinexapac-ethyl (TE)] applied at various rates as standalone products or two-way (FP + TE) and/or three-way $(\mathrm{FP}+\mathrm{PB}+\mathrm{TE})$ mixtures (described in Table 2) in 2017-19 at Bel-Air Country Club, Los Angeles, CA.

\begin{tabular}{|c|c|c|c|}
\hline Treatment & Annual bluegrass cover & Creeping bentgrass injury & NDVI \\
\hline Untreated & 0.17 & -0.83 & 0.41 \\
\hline FP $0.5 \times$ & -0.09 & -0.21 & 0.58 \\
\hline FP $1 \times$ & 0.02 & 0.05 & 0.66 \\
\hline FP $2 \times$ & -0.04 & -0.08 & 0.73 \\
\hline $\mathrm{FP}+\mathrm{TE}$ & -0.15 & 0.18 & 0.78 \\
\hline $\mathrm{FP}+\mathrm{PB}+\mathrm{TE}$ & -0.27 & -0.13 & 0.85 \\
\hline $\mathrm{PB} 1 \times$ & -0.11 & -0.37 & 0.78 \\
\hline PB $1.5 \times$ & -0.10 & -0.24 & 0.73 \\
\hline PB $2 \times$ & -0.06 & -0.09 & 0.76 \\
\hline
\end{tabular}

areas, and it was more severe on previously treated PGR plots. In our situation, discoloration was most likely due to cooler temperatures in March and April and insufficient fertility at the time. When treatments resumed and temperatures and fertility increased, the discoloration diminished.

Previous studies reported variable NDVI indices among differing cultivars of cool-season turfgrass species (Bremer et al., 2011). Although PGR applications resulted in clear and visually perceptible changes in color, no significant differences in NDVI were found between the untreated control and PGR-treated plots in the second year of the study (Fig. 4). This inaccuracy might have resulted from similar NDVI readings on noninjured and nonregulated turf compared with PGR-treated (regulated and darker, but thinner and most likely with lower density) turf. Visual color ratings were positively and significantly correlated with NDVI, but the strength of this correlation varied among treatments. A moderate positive interaction was found for the untreated control and FP $\mathrm{l} \times(\mathrm{r}=$ 0.41 and $r=0.58$, respectively). For most other PGR treatments, the correlation was strong, with correlation coefficients ranging from 0.66 to 0.78 , with the exception of the three-way mixture $(\mathrm{FP}+\mathrm{PB}+\mathrm{TE})$, for which the correlation was considered very strong $(r=0.85)$ (Table 6$)$. Some correlations were observed between NDVI and creeping bentgrass injury; the correlation was significant for FP $0.5 \times(\mathrm{r}=-0.35), \mathrm{PB} \mathrm{l} \times(\mathrm{r}=-0.34)$, and the untreated control $(\mathrm{r}=-0.5 \mathrm{l})$ (Table 5). Our results suggest that NDVI and visual color estimation are not the best methods of assessing the level of injury from PGRs. Rather, those methods can indicate other types of injuries because the change in color was signaling the occurrence of damage only in cases of untreated plots or when low rates of PGRs were used. NDVI was also negatively correlated with annual bluegrass cover, although this correlation was moderate for untreated control $(\mathrm{r}=-0.44)$ and weak for most PGR treatments ( $\mathrm{r}$ values between -0.28 and -0.34 ), except for $\mathrm{PB} 1 \times$ and $\mathrm{PB} 2 \times$, for which correlations were insignificant (data not shown). This suggests that higher annual bluegrass cover resulted in 


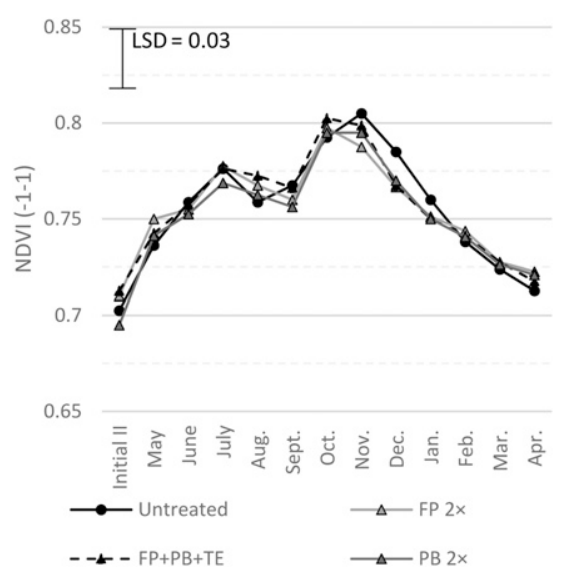

Fig. 4. Effects of selected plant growth regulators flurprimidol (FP), trinexapac-ethyl (TE), and

paclobutrazol (PB) and their two-way $(\mathrm{FP}+\mathrm{TE})$ and/or three-way

$(\mathrm{FP}+\mathrm{PB}+\mathrm{TE})$ mixtures applied at various rates (described in Table 2 ) on the normalized difference vegetation index (NDV) compared with the untreated control in 2018-19 at BelAir Country Club, Los Angeles, CA. Least significant difference values (LSD) are based on Fisher's protected test at $P \leq 0.05$.

lower NDVI; however, the use of PGRs negated those differences.

\section{Conclusions}

Previous research has shown that both FP and PB offer the best suppression of annual bluegrass in creeping bentgrass swards; however, those studies were conducted in different environmental conditions and provided inconclusive results for other parts of the country (Baldwin and Brede, 2011; Branham, 1991; Breuninger, 1993; Isgrigg and Yelverton, 1999a, 1999b). It has also been widely reported that TE does not suppress annual bluegrass populations; therefore, it was not used alone in this study (Bigelow et al., 2007; McCullough et al., 2005; Neylan et al., 1997; Reicher et al., 2015; Rossi, 2001).

Previous research indicated the need for fall applications to support the efficacy of spring-applied PB treatments (Bell et al., 2004). Other research also suggested that multiple PGR applications with an emphasis on perennial biotypes over the course of several years are required to reduce annual bluegrass populations to acceptable amounts (Johnson and Murphy, 1996). Johnson and Murphy
$(1995,1996)$ were able to obtain annual bluegrass cover reduction in creeping bentgrass greens up to $85 \%$ with two sequential sets of applications (in spring and fall) of either PB or FP. In our study, a range of commercially available PGR products was tested as season-long application programs. Among all of the tested PGRs in this study, PB $2 \times$, FP $2 \times$, and the three-way PGR mixture $(\mathrm{FP}+\mathrm{PB}+\mathrm{TE})$ appeared to be the most effective treatments in terms of annual bluegrass suppression. Furthermore, these treatments significantly improved turfgrass color. When considering their safety of use during warm-weather conditions, when applied consecutively throughout the whole season, $\mathrm{PB} 2 \times$ and the threeway PGR mixture $(\mathrm{FP}+\mathrm{PB}+\mathrm{TE})$ seemed to offer the best compromise between the desired annual bluegrass suppression and injury to desirable creeping bentgrass.

All of the PGR rates used in the study were discussed and agreed on with company representatives. The labeled single application and reapplication rate for the use of FP alone on creeping bentgrass putting greens range from 0.062 to $0.250 \mathrm{lb} /$ acre; those rates were used in our study. However, it is important to emphasize that the label also restricts the use of this PGR to $\leq 3.00 \mathrm{lb} /$ acre/year (SePRO, 2020a); therefore, FP 0.5× and $\mathrm{FP} 1 \times$ were the only rates used in our study within the label restrictions. Although FP $2 \times$ could be applied only up to 12 consecutive times at the given rate, the last three applications were already violating the label restrictions. A single application rate of $\mathrm{PB}$ alone recommended for annual bluegrass suppression ranges from 0.25 to $0.50 \mathrm{lb} / \mathrm{acre}$; however, the allowed rate on creeping bentgrass greens ranges from 0.10 to $0.25 \mathrm{lb} /$ acre, thus $0.25 \mathrm{lb} /$ acre should be considered as the maximum labeled rate for annual bluegrass suppression in creeping bentgrass greens. Additionally, the label limits the use of $\mathrm{PB}$ to $2 \mathrm{lb} /$ acre/year; therefore, only eight consecutive applications at the maximum rate are allowed throughout the season (Syngenta Crop Protection, 2020). To provide an extended period of annual bluegrass suppression and allow up to 16 consecutive applications throughout the season within the restricted rate, the maximum rate of $\mathrm{PB}$ alone used in our study $(\mathrm{PB} 2 \times)$ was limited to $0.119 \mathrm{lb} /$ acre. Because multiple rates of FP alone and $\mathrm{PB}$ alone were already included in our study, the available premixes of $\mathrm{FP}+\mathrm{TE}$ and $\mathrm{FP}+\mathrm{PB}+\mathrm{TE}$ were tested. However, due to the space limitations, only one rate of each could be used. The FP+TE treatment was used at the maximum rate labeled for repeated applications (SePRO, 2020b), whereas the $\mathrm{FP}+\mathrm{PB}+\mathrm{TE}$ treatment was used at the medium rate labeled for reapplications with the consideration of use restrictions in early spring and late fall (SePRO, 2020c). Because FP+PB+TE resulted in satisfactory annual bluegrass suppression and limited turfgrass injury, more emphasis should be placed on the determination of the most effective but safe rate of this product.

Based on the inconclusive NDVI results affected by a number of factors, with the color/thinning relationship being the major one, it is recommended that other objective measurements such as digital image analysis with canopy density measurements should be used in future studies to evaluate PGR safety. As Bigelow et al. (2007) pointed out, it is also recommended that future studies should focus on the most effective treatments used together with safeners to mask or reduce potential discoloration and thinning.

\section{Literature cited}

Adams, J.C. 1989. Control of Poa annua in cool-season turf with ethofumesate. Proc. Can. Turfgrass Conf. 40:19-20.

Askew, S.D. 2017. Plant growth regulators applied in winter improve annual bluegrass (Poa annua) seedhead suppression on golf greens. Weed Technol. 31:701-713, doi: 101017/wet.2017.73.

Askew, S.D. and B.M.S. McNulty. 2014. Methiozolin and cumyluron for preemergence annual bluegrass (Poa annua) control on creeping bentgrass (Agrostis stolonifera) putting greens. Weed Technol. 28:535-542, doi: 10.1614/WT-D14-00018.1.

Baldwin, N.A. 1993. Chemical control of Poa annua: A review. J. Sports Turf Res. Inst. 69:7-19.

Baldwin, C.M. and A.D. Brede. 2011. Plant growth regulator selection and application rate influence annual bluegrass control in creeping bentgrass putting 
greens. Appl. Turfgrass Sci. doi: 10.1094/ ATS-201 1-0517-02-RS.

Bell, G., C. Stiegler, and K. Koh. 2004. Poa control: Perhaps there's hope: Applications of paclobutrazol reduce annual bluegrass cover in putting greens. Golf Course Mgt. 72:123-126.

Bigelow, C.A., G.A. Hardebeck, and B.T. Bunnel. 2007. Monthly flurprimidol applications reduce annual bluegrass populations in creeping bentgrass fairway. Appl. Turfgrass Sci. doi: 10.1094/ATS2007-0508-02-RS.

Branham, B. 1991. Dealing with Poa annua. Golf Course Mgt. 59:46-60.

Breeden, S.M., J.T. Brosnan, T.C. Mueller, G.K. Breeden, B.J. Horvath, and S.A. Senseman. 2017. Confirmation and control of annual bluegrass (Poa annua) with resistance to prodiamine and glyphosate. Weed Technol. 31:111-119, doi: 10.1614/WT-D-16-00084.1.

Bremer, D.J., H. Lee, K. Su, and S.J. Keeley. 2011. Relationships between normalized difference vegetation index and visual quality in cool-season turfgrass: I. Variation among species and cultivars. Crop Sci. 51:2212-2218.

Breuninger, J. 1993. Poa annua control in bentgrass greens. Golf Course Mgt. 61:68-73.

Brosnan, J.T., G.M. Henry, G.K. Breeden, T. Cooper, and T.J. Serensits. 2013. Methiozolin efficacy for annual bluegrass (Poa annua) control on sand- and soilbased creeping bentgrass putting greens. Weed Technol. 27:310-316, doi: 10.1614/WT-D-12-00123.1.

Cross, R.B., W.C. Bridges, Jr., L.B. McCarty, and J.S. McElroy. 2015. Evaluating annual bluegrass herbicide resistance evolution in golf course fairways. Weed Technol. 29:488-500, doi: 10.1614/WT-D-14-00151.1.

Ervin, E.H., N. Reams, X. Zhang, A. Boyd, and S. Askew. 2017. An integrated nutritional and chemical approach to $P o a$ annua suppression in creeping bentgrass greens. Crop Sci. 57:567-572, doi: 10.2135/cropsci2016.05.0308.

Flessner, M.L., G.R. Wehtje, and J.S. McElroy. 2013. Methiozolin absorption and translocation in annual bluegrass ( $\mathrm{Poa}$ annua). Weed Sci. 61:201-208, doi: 10.1614/WS-D-12-00128.1.

Flessner, M.L., J.S. McElroy, and J.D. McCurdy. 2017. Annual bluegrass (Poa annua) control with methiozolin and nutrient tank-mixtures. Weed Technol. 31:761-768, doi: 10.1017/wet.2017.40.

Gaussoin, R.E. and B.E. Branham. 1987. Annual bluegrass and creeping bentgrass germination response to flurprimidol. HortScience 22:441-442.

Gaussoin, R.E. and B.E. Branham. 1989. Influence of cultural factors on species dominance in a mixed stand of annual bluegrass/creeping bentgrass. Crop Sci. 29:480-484, doi: $10.2135 /$ cropscil989.0011183X002900020048x.

Golfdom. 2019. EPA grants unconditional registration of PoaCure. 9 Apr. 2020. <https://www.golfdom.com/epa-grantsunconditional-registration-of-poacure $/>$.

Green, T.O., A. Kravchenko, J.N. Rogers, III, and J.M. Vargas, Jr. 2019. Annual bluegrass: Emergence of viable seed in various putting green sites and soil removal depths. HortTechnology 29:438442, doi: 10.21273/HORTTECH0434519.

Haguewood, J.B., E. Song, R.J. Smeda, J.Q. Moss, and X. Xiong. 2013. Suppression of annual bluegrass seedheads with mefluidide, ethephon, and ethephon plus trinexapac-ethyl on creeping bentgrass greens. Agron. J. 105:1832-1838, doi: 10.2134/agronj2013.0220.

Haley, J.E. and T.W. Fermanian. 1989. Flurprimidol effect on the emergence and growth of annual bluegrass and creeping bentgrass. Agron. J. 81:198-202, doi: 10.2134/ agronj1989.00021962008100020012x.

Han, K.M., J.E. Kaminski, and T.T. Lulis. 2017. Influence of nitrogen, plant growth regulators, and iron sulfate on annual bluegrass populations on a golf green. Intl. Turfgrass Soc. Res. J. 13:661-669, doi: 10.2134/itsrj2016.05.0402.

Heap, I. 2020. The international herbicide-resistant weed database. 9 Apr. 2020. $<$ http://www.weedscience.org $>$.

Hoisington, N.R., M.L. Flessner, M. Schiavon, J.S. McElroy, and J.H. Baird. 2014. Tolerance of bentgrass (Agrostis) species and cultivars to methiozolin. Weed Technol. 28:501-509, doi: 10.1614/WT-D-13-00114.1.

Isgrigg, J., III and F.H. Yelverton. 1999a. New approaches to management of annual bluegrass in bentgrass putting greens. Proc. Southern Weed Sci. Soc. 52:72.

Isgrigg, J., III and F.H. Yelverton. 1999b. Transition of Poa annua spp. reptans infested bentgrass putting greens to monoculture bentgrass using plant growth regulators. Proc. Southern Weed Sci. Soc. 52:76-77.

Jeffries, M.D., F.H. Yelverton, and T.W. Gannon. 2013. Annual bluegrass (Poa annua) control in creeping bentgrass putting greens with amicarbazone and paclobutrazol. Weed Technol. 27:520 526, doi: 10.1614/WT-D-12-00144.1.
Johnson, B.J. and T.R. Murphy. 1995. Effect of paclobutrazol and flurprimidol on suppression of Poa annua spp. reptans in creeping bentgrass (Agrostis stolonifera) greens. Weed Technol. 9:182-186, doi: $10.1017 /$ S0890037X00023150.

Johnson, B.J. and T.R. Murphy. 1996. Suppression of a perennial subspecies of annual bluegrass (Poa annua spp. reptans) in a creeping bentgrass (Agrostis stolonifera) green with plant growth regulators. Weed Technol. 10:705-709, doi: 10.1017/S0890037X00040689.

Kageyama, M.E., L.R. Widell, D.G. Cotton, and G.R. McVey. 1989. Annual bluegrass to bent conversion with a turf growth retardant (TGR). Proc. Intl. Turfgrass Res. Conf 6:387-390.

Koski, A.J. 1997. Influence of paclobutrazol on creeping bent (Agrostis stolonifera L.) root production and drought resistance. Intl. Turfgrass Soc. Res. J. 8:699-709.

Kreuser, W.C., G.R. Obear, D.J. Michael, and D.J. Soldat. 2018. Growing degreeday models predict the performance of paclobutrazol on bentgrass golf putting greens. Crop Sci. 58:1402-1408, doi: $10.2135 /$ cropsci2017.06.0395.

McCullough, P.E., D.G. de Barreda, and J. Yu. 2013. Selectivity of methiozolin for annual bluegrass (Poa annua) control in creeping bentgrass as influenced by temperature and application timing. Weed Sci. 61:209-216, doi: 10.1614/WS-D12-00135.1.

McCullough, P.E., S.E. Hart, and D.W. Lycan. 2005. Plant growth regulator regimens reduce Poa annua populations in creeping bentgrass. Appl. Turfgrass Sci., doi: 10.1094/ATS-2005-0304-01-RS.

Miller, G.L. 2016. Effect of watered-in demethylation-inhibitor fungicide and paclobutrazol applications on foliar disease severity and turfgrass quality of creeping bentgrass putting greens. Crop Prot. 79:64-69, doi: 10.1016/j.cropro.2015.10.008.

Neylan, J., D. Nickson, M. Robinson, and P. Manning. 1997. Control of Poa annua in creeping bent (Agrostis stolonifera) greens. Intl. Turfgrass Soc. Res. J. 8:1398-1406.

Patton, A.J., R.C. Braun, G.P. Schortgen, D.V. Weisenberger, B.E. Branham, B. Sharp, M.D. Sousek, R.E. Gaussoin, and Z.J. Reicher. 2019. Long-term efficacy of annual bluegrass control strategies on golf course putting greens. Appl. Turfgrass Sci., doi: 10.2134/cftm2018.09.0068.

Raley, R.B., P.J. Landschoot, and J.T. Brosnan. 2013. Influence of phosphorus and nitrogen on annual bluegrass en- 
croachment in a creeping bentgrass putting green. Intl. Turfgrass Soc. Res. J. 12:649-655.

Reicher, Z., M. Sousek, A. Patton, D. Weisenberger, A. Hathaway, and R. Calhoun. 2015. Annual bluegrass control on putting greens from three or four years of season-long applications of herbicides or plant growth regulators in three states. Crop Forage Turfgrass Mgt., doi: 10.2134/ cftm2014.0050.

Rossi, F.S. 2001. Annual bluegrass population dynamics in response to growth regulators and herbicides. Intl. Turfgrass Soc. Res. J. 9:906-909.

SePRO. 2020a. Cutless MEC specimen label. 18 Oct. 2020. <https://www. sepro.com/Documents/Cutless-MEC_ Label.pdf>.
SePRO. 2020b. Legacy specimen label. 18 Oct. 2020. <https://www.sepro. com/Documents/Legacy_Label.pdf $>$.

SePRO. 2020c. Musketeer specimen label. 18 Oct. 2020. <https://www.sepro. com/Documents/Musketeer_Label. pdf>.

Shoop, G.J., R.H. Hoefer, and D.G. Ortega. 1986. Flurprimidol (EL-500) growth regulator effect on bentgrass fairways in the Northeast. Proc. Annu. Mtg. Northeastern Weed Sci. Soc. 40:131.

Syngenta Crop Protection. 2020. Trimmit 2SC specimen label. 18 Oct. 2020. <https://www.greencastonline.com/ current-label/trimmit $\% 202 \mathrm{sc}>$.
Turgeon, A.J. 2012. Turfgrass management. 9 th ed. Prentice Hall, Upper Saddle River, NJ.

Woosley, P.B., D.W. Williams, and A.J. Powell. 2003. Postemergence control of annual bluegrass (Poa annua spp. reptans) in creeping bentgrass (Agrostis stolonifera) turf. Weed Technol. 17:770-776, doi: 10.1614/WT02-153.

Xiong, X., J.Q. Moss, J.B. Haguewood, and K. Koh. 2015. Safety of sequential fall methiozolin applications on creeping bentgrass putting greens. Crop Forage Turfgrass Mgt., doi: 10.2134/cftm2014.0079.

Yelverton, F.H. 2015. Poa annua management on golf course putting greens. USGA Green Sect. Rec. 53:1-9. 